\title{
チーム演習で個人が自覚したミステイクの起こし方と 心理学的タイプとの連関の検討
}

A Study on Associations between Occurrence Patterns of Mistake, Which Individual Realized in Team Exercises, and Psychological Type
杉本洋一
荒 川 雅 生 ${ }^{* 1}$
Yoichi SUGIMOTO
Masao ARAKAWA
清 水 裕 $3 * 2$
Hiroko SHIMIZU
石丸昌 彦*3
Masahiko ISHIMARU

\begin{abstract}
This study aimed to verify whether there were associations between the patterns of mistakes realized by an individual member and Jungian psychological type of the individual. The survey was performed on 250 subjects, of which 160 (127 men and 33 women, mean age \pm SD $=18.8 \pm 0.7$ years) were included in the statistical analysis using Mantel-Haenszel test and Fisher's exact test. The results suggested that Jungian psychological type served as a basis of cognitive style in many aspects Specifically, for example, in the association of occurrence of mistake due to misconception, intuition type was statistically significant $(p<.01)$. It should also be noted that the psychological type could have an adverse effect, especially when the individual failed to adapt to the given situation. These results present a clue to promote complementary cooperation in teamwork education, although further studies are required.
\end{abstract}

Keywords : Teamwork Education, Jung's Psychological Type, Human Error, Mistake キーワード：チームワーク教育，ユングのタイプ論，ヒューマンエラー，ミステイク

\section{1. 序論}

チームワークは, 働くうえでの汎用的能力であること, 学士力に示されていること ${ }^{1)}$, イノベーション創出にと って有用であること ${ }^{2)}$ 等の理由で重要な教育テーマであ る.このようなニーズに対応するため, 香川大学では, 平成30年度に創造工学部の初年次共通教育の位置づけで 「チームワーキング演習」（以下，授業という）を開設・ 開講した。授業では，ユングのタイプ論を用いて自己理 解・他者理解を促進し，それを土台にして相補的協働に 資する知識やスキルを修得させている.チーム演習では, 課題達成に失敗するチームが毎回発生しているが，J.リ ーズン（Reason, 1990）の定義によるヒューマンエラー の形式 (表 1 $)^{3)}$ の中の, 目標の計画段階で誤るミステ イクに該当する失敗が多く観察された。 そこで，個人の

表 1 認知段階に従った主要なエラーの分類 (リーズン, 1994 林訳，1990より) ${ }^{3)}$

\begin{tabular}{|c|c|}
\hline 認知段階 & 主要エラー形式 \\
\hline 計画 & ミステイク \\
\hline 考察 & ラプス \\
\hline 実行 & スリップ \\
\hline
\end{tabular}

2020 年 2 月 25 日受付

※1香川大学創造工学部

※2香川大学医学部

※3 放送大学教養学部
ミステイクとタイプとの関連性に関心をもつようになっ たが, 国内外の先行研究の中に, 演習中のヒューマンエ ラーをユングのタイプ論から分析したものは見当たらな かった ${ }^{4)}$ 。このため, 授業に取り入れる知見を得るとい う観点から, 授業の演習結果の検証を試みることにした。 本研究の目的は, チーム演習で個人が自覚したミステイ クの起こし方と心理学的タイプとの間に, 連関があるか を検証することである.

\section{2. 心理学的タイプ}

性格の捉え方については，個人差を相対比較の視点で 捉える特性論と，個人差を絶対的な視点で捉える類型論 がある．授業では，類型論に属するユング心理学の夕イ プ論（以下では，タイプ論と呼ぶ）を背景理論にした。 なお， タイプという用語は多義的に使われているが，授 業では, 主機能・補助機能といった機能の序列について は扱わず，単に個人がどの極を指向しているかという意 味に限定して使用した。 また，授業でのタイプ論の説明 は, 公知範囲の内容を, 市販本 ${ }^{5)}$ をテストにして行っ た. 以下では, 授業に利用したタイプ論の概要を示す ${ }^{6)}$. まず，タイプ論では，人の習慣的な行動は，興味・関 心の向け方の方向性と心のプロセス (知覚と判断) のあ る一定のパターンの表れであるとする。なお，タイプは あくまでも一般的な反応であるため, 個々人の反応をス テレオタイプに決めつけるものではない. 次に, タイプ 論では, 心理学的両極性（二律背反の関係にある両極構 造）で心の中を理解する。 そして，どちらの極を指向す 
態度 (構え) の類型

\begin{tabular}{|c|c|c|c|c|c|}
\hline \multirow{2}{*}{$\begin{array}{r}\text { 外向 } \\
(\mathrm{E})\end{array}$} & \multirow{2}{*}{$\begin{array}{c}\text { 内向 } \\
\text { ( I ) }\end{array}$} & \multicolumn{2}{|c|}{ 知覚 } & \multicolumn{2}{|c|}{ 判断 } \\
\hline & & $\begin{array}{l}\text { 感覚 } \\
\text { ( S ) }\end{array}$ & $\begin{array}{l}\text { 直観 } \\
(\mathrm{N})\end{array}$ & $\begin{array}{l}\text { 思考 } \\
(\mathrm{T})\end{array}$ & $\begin{array}{l}\text { 感情 } \\
(\mathrm{F})\end{array}$ \\
\hline
\end{tabular}

図 1 タイプ論のフレームワーク $(\text { 杉本ら，2019より })^{7)}$

るかで一般的な反応に違いが生じると考える. 指向とは, 一方の極が優先的に機能することで，その極は生まれつ き決まっているとする．日常生活では両極とも機能して いるが，両極が同時に機能することはない，ただ，指向 している極は，先に，楽に，うまく機能する，以上を踏 まえて，指向する極（以下，タイプという）の違いによ って生じる一般的な反応の違いについて説明する.なお, 4 つの心理機能の名称記載において, 以下, 機能の表記 は省略する。

興味・関心の向け方の方向性に関する両極は, 外向 (Extraversion；E）と内向（Introversion；I）である. 外向タイプは，客体である外界との関わりを求め，内向 タイプは，主体である自分の内界との関わりを求める. これが, 構え（一定の方向に作用ないし反応しょうとす る準備態勢）になる，外向夕イプは，順応的に反応しよ うとする性向があり，内向タイプは吟味的に反応しょう とする性向がある.

心理機能のうち知覚に関する両極は，五感を通じて認 識される情報を取り入れる感覚 (Sensing; S ) と抽象的・ 俯瞰的に認識される情報を取り入れる直観（Intuition； N）である，感覚タイプは，「いま，ここ，現実」に反 応しょうとする性向があり，直観タイプは「将来，可能 性，観念」に反応しょうとする性向がある。一方，心理 機能のうち判断に関する両極は, 論理的・分析的に判断 する思考（Thinking；T）と調和的・協調的に判断する 感情（Feeling；F）である。思考夕イプは，「論理的， 分析的」に反応しょうとする性向があり，感情タイプは 「共感的, 支援的」に反応しょうとする性向がある. 図 1 は, タイプ論のフレームワークであり, 構えの 2 極と心 理機能の 4 極の位置づけを示している.

ここでチームの協調設計 (Collaborative Design) ${ }^{8)}$ に おいて, タイプ論を利用した先行研究についてみる。 パ イオニア的な位置づけにあるのが, Teamology（Wilde, 2009) ${ }^{9)}$ である. Teamologyでは, タイプの違いを活か す観点から，チーム内の役割分担を考えていく，その際 のチームに必要な役割とタイプとの関係を示したのが図 $2^{10)}$ である. 図 2 には, 2 つ正方形（以下では, 左の 正方形, 右の正方形と呼ぶことにする）が並んでいるが, それぞれ縦線・横線・対角線を境にして, 構えと心理機 能のタイプの組み合わせがあり，8つの領域に分かれて いる。.まず，両方の正方形とも，横線を境にして，上側 が外向タイプ, 下側が内向タイプとなっている. 次に, 左側の正方形は, 縦線を境にして, 左側が感覚タイプ, 右側が直観タイプとなっており, 右側の正方形は, 縦線 を境にして, 左側が思考タイプ, 右側が感情タイプにな っている. 以下では, 図 2 で示された役割付与の背景を,

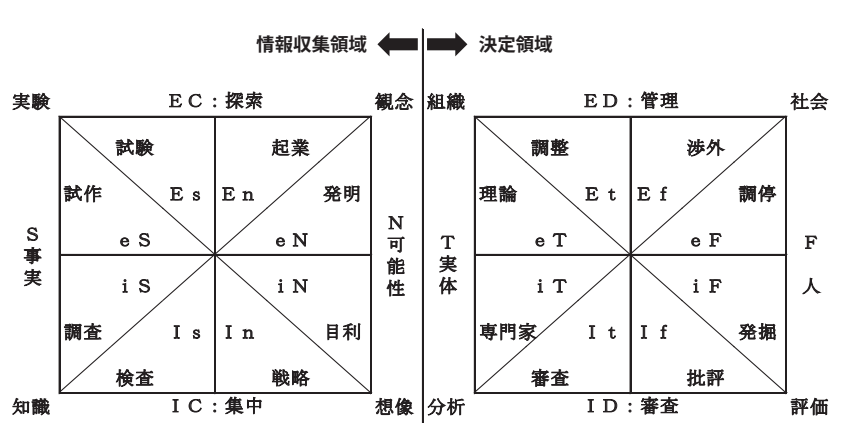

図 2 チームに必要な役割（飯野，2007より $)^{10)}$

タイプ論に基づく解釈 ${ }^{11)}$-12) により簡潔に説明する。な お，指向する極の名称記載において，以下，タイプの表 記は，省略する，

構えが外向で知覚機能が感覚の場合 (左の正方形の上 側左領域）は, 性向として, action-oriented realists ${ }^{12)}$ な 反応の仕方になりやすい，そのため, 試験や試作の役割 が例示されている．構えが内向で知覚機能が感覚の場合 (左の正方形の下側左領域) は, 性向として, thoughtful realists ${ }^{12)}$ な反応の仕方になりやすい. そのため, 検査 や調查の役割が例示されている. 構えが外向で知覚機能 が直観の場合（左の正方形の上側右領域）は, 性向とし て, action-oriented innovators ${ }^{12)}$ な反応の仕方になりや すい，そのため，起業や発明の役割が例示されている. 構えが内向で知覚機能が直観の場合 (左の正方形の下側 右領域）は, 性向として, see to the heart of important problems ${ }^{12)}$ な反応の仕方になりやすい. そのため, 戦略 や目利の役割が例示されている. 構えが外向で判断機能 が思考の場合（右の正方形の上側左領域）は, 性向とし て, action-oriented thinkers ${ }^{12)}$ な反応の仕方になりやす い. そのため, 調整や理論の役割が例示されている。構 えが内向で判断機能が思考の場合（右の正方形の下側左 領域）は, 性向として, reflective reasoners ${ }^{12)}$ な反応の 仕方になりやすい，そのため, 審査や専門家の役割が例 示されている. 構えが外向で判断機能が感情の場合（右 の正方形の上側右領域）は, 性向として, action-oriented cooperators $^{12)}$ な反応の仕方になりやすい. そのため, 涉 外や調停の役割が例示されている. 構えが内向で判断機 能が感情の場合（右の正方形の下側右領域）は, 性向と して, care about values and people ${ }^{12)}$ な反応の仕方にな りやすい，そのため, 批評や発掘の役割が例示されてい る.

\section{3. 方法}

\section{1 調查対象}

令和元年度の第 2 クォーター ( 6 月〜 7 月), 第 3 クォ ーター（10月～12月上旬)，第 4 クォーター（12月上旬 〜 月) で, 授業を履修した計 6 クラスの者（全員 1 年 生）のうち, 連続欠席等の理由で研究協力の同意を得ら れなかった 4 名を除いた250名（男性201名，女性49名） を調査対象とした。なお, 本研究は, 香川大学工学部研 究倫理審査委員会の承認を受けた（受付番号30-006）. 


\section{2 調查方法}

授業 (90分/コマの 2 コマ連続が 1 回. 全 8 回実施) の 中で, 課題の異なるチーム演習を計 5 回実施した。履修 者には，各演習の実施直後にふりかえりをさせるととも に，期末レポートにおいて，全体を通じたふりかえりを させた，具体的な実施方法は次のとおりであった．

（1）演習チームの編成

あらかじめ履修者にはクラス通し番号をつけた．各演 習の準備として, クラス通し番号をランダムに並べ替え て演習用通し番号をつけ直した。 その演習用通し番号を 1 番から順に 4 名標準で区切りチーム編成表を作成し た。なお，久席者が出て 2 名以下のチームが生じたとき は，そのメンバーを他チームに編入する調整をした。

（2）チーム演習の課題

課題は，パスワードをつけたMicrosoft Wordに書い ており, 演習の開始前に, 各自でMoodleからダウロー ドさせた，教員は，演習開始時にパスワードを口頭周知 した，教室前方のスクリーンに，デジタルタイマーを映 写した。課題の指示内容は, 本文と注書きを読まなけれ ば, 正確に理解できないようにした。計 5 回（演習 A〜 E）の課題の概要は以下のとおりであった。 なお，制限 時間は, 課題 $\mathrm{A} \sim \mathrm{D}$ を20分, 課題 $\mathrm{E}$ を40分とした.

課題 A：A 4 コピー用紙を材料にしてペーパータワー を作成させた，成果は高さとした，初回演習のため, 演 習回の進行手順を覚えさせることを主眼にした。なお， 紙を使用したのは，2回目以降で使用するパス夕に慣れ させないためであった。

課題 B：パスタを材料にして張り出し部分のある自立 構造物を作成させた. 成果は張り出し部分の水平距離と した.この課題では，上ではなく横に伸びた部分をつく るということを正しく認識することが重要であったが, それを読み取るための手掛かり言葉は, 最低限にして, 2 語（張り出し, 水平距離）だけにした.

課題C：パス夕を材料にして自立構造物を作成させ, その頭頂部分に 5 円玉を入れさせた，成果は，ポイント 制にし，ポイントの計算は，突起部分に差し込んだ 5 円 玉の枚数と一番高いところにある 5 円玉の高さの積とし た。な㧍，注書きをよく読めば，突起部分を手で支える ことも可能であることが解釈できるようにした。

課題 D : パス夕を材料にしてパスタタワーを作成させ た，成果は高さとした，初回演習と似ているが，使用資 材が異なることやタワー先端にマシュマロを刺さなけれ ばならないことで, 課題 $\mathrm{A} の$ 経験が単純には生かせない ようにした。

課題 $\mathrm{E} ： 1$ 枚の写真（社会問題に関する報道写真）を 見せて, 解決すべき課題（現状のありたい姿からの乘離） や問題（現状のあるべき基準からの逸脱）が何であるか を考えさせた，そのうえで，チームとして提案したい解 決方法を，パス夕を材料にして自由に表現させた．作品 の趣旨と出来栄えを評価観点にして, 全員（教員を除く） による投票を行った。成果は投票結果の順位とした。

(3) 用語の操作的定義

本研究では, 調查に必要な範囲で次の用語を操作的に
定義した. ヒューマンエラーは「本人が, 演習中の活動 過程で起こした失敗」,起因は「ヒューマンエラーの発生 の誘発要因になった人的要因」, 自覚したとは,「自分に 関する問題意識をもった」と定義して説明した. ヒュー マンエラーのエラー形式については, ミステイクを「ヒ ユーマンエラーのうち, 達成すべき課題の同定を誤って しまい, その誤った課題に向けて行動してしまったも の」, ラプスを「ヒューマンエラーのうち, 課題達成に向 けた活動過程で, 意図していた行為をうっかりし忘れた もの」, スリップを「ヒューマンエラーのうち, 課題達成 に向けた活動過程で, 意図した行為が意図したように実 行できなかったもの」と定義した，なお，ヒューマンエ ラーがなかったという者については，とくになし，とし た. ヒューマンエラーのうちミステイクについては, そ

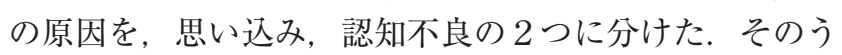
えで, 思い込みを「指示書の解釈において, 自己の先行 経験や固定観念に基づく解䣋をしてしまったことが, 達 成すべき課題の同定失敗の原因であった場合」, 認知不 良を「指示書の解釈において, 読み込み不足による指示 内容の不完全な認知が, 達成すべき課題の同定失敗の原 因であった場合」と定義した。ささらに，認知不良につい ては, 起因を, 外因, 内因の 2 つに分け, 外因を「起因 が，本人の周囲にいた者にあったとき」，内因を「起因 が，本人自身にあったとき」と定義した.

（4）個人が自覚した起こしやすいヒューマンエラー

まず，履修者が，起こしやすいヒューマンエラーにつ いて自覚していくよう, 演習ごとに演習後のアンケート を実施し，ヒューマンエラーの発生有無と発生した場合 はその内容を回答させた。 そのうえで, 期末レポートに おいて, 履修者が自覚した起こしやすいヒューマンエラ 一について自由記述をさせた。履修者が自覚した起こし やすいヒューマンエラーの同定については, 用語の操作 的定義を判断基準にして, 期末レポートの記述内容に基 づいて分類した．また，分類を確かなものにするため, 必要があれば, 各演習で実施したふりかえりアンケート の回答も参照した。

（5）個人が自覚した指向する方の極

まず，履修者が，自分のタイプについて内省を梁める よう, 各演習の実施後にふりかえりアンケートを実施し, タイプの極を推定させた，そのうえで, 期末レポートに おいて, その時点での夕イプの推定とその理由を記述さ せた，なお，履修者が，期末レポートに書いたタイプを 自分への決めつけに使わないようにするため, 今後, 自 分の意思で修正してよいことを繰り返し周知した。

\section{3 分析方法}

(1) 分析項目

分析項目 1 ：自覚した起こしやすいヒューマンエラー がミステイクになった調査対象者を分析対象者として, タイプとミステイクの原因の連関を検証した.

分析項目 2 ：自覚した起こしやすいヒューマンエラー がミステイクになり, かつ, その原因が認知不良になっ た調査対象者を分析対象者として, タイプと認知不良の 起因の連関を検証した。 
表 2 個人が推定した自分のタイプと自覚したエラー形式のクロス表

\begin{tabular}{|c|c|c|c|c|c|c|c|}
\hline & \multicolumn{4}{|c|}{ 個人が自覚したヒューマンエラーの様式 } & \multirow{2}{*}{ 計 } \\
\hline & & & ミステイク & ラプス & スリップ & とくになし & \\
\hline \multirow{9}{*}{$\begin{array}{l}\text { 個人が推定し } \\
\text { た自分のタイ } \\
\text { プ }\end{array}$} & \multirow{3}{*}{ 構え } & 外向 & $53(21.2)$ & $8(3.2)$ & $10(4.0)$ & $11(4.4)$ & $82(32.8)$ \\
\hline & & 内向 & $107(42.8)$ & $10(4.0)$ & $20(8.0)$ & $31(12.4)$ & $168(67.2)$ \\
\hline & & 計 & $160(64.0)$ & $18(7.2)$ & $30(12.0)$ & $42(16.8)$ & $250(100.0)$ \\
\hline & \multirow{3}{*}{ 知覚機能 } & 感覚 & $83(33.2)$ & $9(3.6)$ & $17(6.8)$ & $25(10.0)$ & $134(53.6)$ \\
\hline & & 直観 & $77(30.8)$ & $9 \quad(3.6)$ & $13(5.2)$ & $17(6.8)$ & $116(46.4)$ \\
\hline & & 計 & $160(64.0)$ & $18(7.2)$ & $30(12.0)$ & $42(16.8)$ & $250(100.0)$ \\
\hline & \multirow{3}{*}{ 判断機能 } & 思考 & $99(39.6)$ & $12(4.8)$ & $18(7.2)$ & $26(10.4)$ & $155(62.0)$ \\
\hline & & 感情 & $61(24.4)$ & $6 \quad(2.4)$ & $12(4.8)$ & $16(6.4)$ & $95(38.0)$ \\
\hline & & 計 & $160(64.0)$ & $18(7.2)$ & $30(12.0)$ & $42(16.8)$ & $250(100.0)$ \\
\hline
\end{tabular}

Note. カッコ内は全数（250）に占める割合（\%).

\section{(2) 統計解析}

統計ソフトは, IBM-SPSS-Statistics（バージョン26） を用い，5\%を有意水準とした。また，有意のときは， 調整済み残差によって残差分析をした。残差の有意性検 定では, | 残差 $\mid>1.96$ のとき $p<.05$, | 残差 $\mid>2.58$ の とき $p<.01$ とした.

分析項目 1 :まず, クロス表において, 表側を構え（外 向, 内向）で層別した知覚機能（感覚, 直観）にし, 表 頭をミステイクの原因（思い込み, 認知不良) にして, マンテル・ヘンツェル検定を行った。次に，クロス表に おいて，表側を構え（外向, 内向）で層別した判断機能 (思考, 感情) にし，表頭をミステイクの原因（思い込 み, 認知不良）にして, マンテル・ヘンツェル検定を行 った。

分析項目 $2:$ :ず, クロス表において, 表側を構え（外 向, 内向）で層別した知覚機能（感覚, 直観）にし, 表 頭を認知不良の起因（外因，内因）にして，マンテル・ ヘンツェル検定を行った。次に，クロス表において，表 側を 4 種類の夕イプ組み合わせ（外向・感覚, 外向・直 観, 内向・感覚, 内向・直観）にし, 表頭を認知不良の 起因（外因, 内因）にして, フィッシャーの正確確率検 定を行った。

\section{4. 結果と考察}

\section{1 調査対象人数}

調査対象者は, 250名（男性201名，女性49名）であっ た. 調査対象者のタイプと自覚した起こしやすいヒュー マンエラーの形式をクロス表に示した（表 2 ）。調査対 象者全体についてみると, タイプの推定では, 内向, 感 覚，思考の割合が高くなった。 これは授業の他の全クラ スで同様であり，それに一致するものであった。

\section{2 分析対象人数}

自覚した起こしやすいヒューマンエラーがミステイク になった調査対象者は, 160名（男性127名, 女性33名） であった。平均年齢は, 18.8歳（標準偏差 0.7 歳）であっ た.この160名を分析対象者とした。

\section{3 ミステイクの原因（分析項目 1)}

分析対象者について, 知覚機能のタイプ (感覚, 直観) の違いが, ミステイクにおける原因（思い込み, 認知不
表 3 知覚機能のタイプとミステイクの原因のクロス表

\begin{tabular}{|c|c|c|c|c|}
\hline \multicolumn{2}{|c|}{} & \multicolumn{2}{|c|}{ ミステイクの原因 } & \multirow{2}{*}{ 計 } \\
\cline { 3 - 4 } \multicolumn{2}{|c|}{} & 思い込み & 認知不良 & \multicolumn{1}{|c|}{} \\
\hline \multirow{3}{*}{ 外向 } & 感覚 & $7(12.3)$ & $18(12.7)$ & 25 \\
\cline { 2 - 4 } & 直観 & $19(13.7)$ & $9(14.3)$ & 28 \\
\cline { 2 - 4 } & 計 & $26(26.0)$ & $27(27.0)$ & 53 \\
\hline \multirow{3}{*}{ 内向 } & 感覚 & $19(32.5)$ & $39(25.5)$ & 58 \\
\cline { 2 - 4 } & 直観 & $41(27.5)$ & $8(21.5)$ & 49 \\
\cline { 2 - 4 } & 計 & $60(60.0)$ & $47(47.0)$ & 107 \\
\hline \multicolumn{2}{|c|}{ 計 } & 86 & 74 & 160 \\
\hline
\end{tabular}

Note. カッコ内は期待度数.

表 4 知覚機能のタイプとミステイクの原因の残差分析

\begin{tabular}{|c|c|c|c|}
\hline & \multicolumn{2}{|c|}{ ミステイクの原因 } \\
\hline & & 思い込み & 認知不良 \\
\hline \multirow{2}{*}{ 外向 } & 感覚 & $-2.898^{* *}$ & $2.898^{* *}$ \\
\hline & 直観 & $2.898 * *$ & $-2.898^{* *}$ \\
\hline \multirow{2}{*}{ 内向 } & 感覚 & $-5.287 * *$ & $5.287^{* *}$ \\
\hline & 直観 & $5.287^{* *}$ & $-5.287^{* *}$ \\
\hline
\end{tabular}

良）の違いに連関しているかを検証した。表 3 は，個人 が推定した知覚機能のタイプ (感覚, 直観) と, 個人が 自覚したミステイクの原因のクロス表である.

知覚機能の夕イプを構えのタイプ (外向, 内向) で層 別化したマンテル・ヘンツェル検定を行った結果, 漸近 有意確率 (両側) : $p=0.0000000069<.01$, 推定值 0.122 , $95 \%$ CI $[0.59,0.253]$ となり, 統計的に有意な連関が危 険率 $1 \%$ で認められた。

そこで残差分析を行ったところ, 表 4 の結果になった. 原因を思い込みとした者については, 構えのタイプにか かわらず, 直観が有意に多く $(p<.01)$, 感覚が有意に 少なかった $(p<.01)$. 一方, 原因を認知不良とした者 については, 構えのタイプにかかわらず, 感覚が有意に 多く $(p<.01)$, 直観が有意に少なかった $(p<.01)$.

また, 判断機能のタイプ (思考, 感情) の違いが, ミ ステイクにおける原因（思い込み, 認知不良) の違いと 連関しているかについても検証した. 表 5 は, 判断機能 
表 5 判断機能のタイプとミステイクの原因のクロス表

\begin{tabular}{|c|c|c|c|c|}
\hline \multicolumn{2}{|c|}{} & \multicolumn{2}{|c|}{ ミステイクの原因 } & \multirow{2}{*}{ 計 } \\
\cline { 3 - 4 } \multicolumn{2}{|c|}{} & 思い込み & 認知不良 & \multicolumn{1}{|c|}{} \\
\hline \multirow{3}{*}{ 外向 } & 思考 & $14(14.2)$ & $15(14.8)$ & 29 \\
\cline { 2 - 4 } & 感情 & $12(11.8)$ & $12(12.2)$ & 24 \\
\cline { 2 - 4 } & 計 & $26(26.0)$ & $27(27.0)$ & 53 \\
\hline \multirow{3}{*}{ 内向 } & 思考 & $39(39.3)$ & $31(30.7)$ & 70 \\
\cline { 2 - 4 } & 感情 & $21(20.7)$ & $16(16.3)$ & 37 \\
\cline { 2 - 4 } & 計 & $60(60.0)$ & $47(47.0)$ & 107 \\
\hline \multicolumn{2}{|c|}{ 計 } & 86 & 74 & 160 \\
\hline
\end{tabular}

Note. カッコ内は期待度数.

表 6 知覚機能のタイプと認知不良の起因のクロス表

\begin{tabular}{|c|c|c|c|c|}
\hline & \multicolumn{2}{|c|}{ 認知不良の原因 } & \multirow{2}{*}{ 計 } \\
\hline & & 外因 & 内因 & \\
\hline \multirow{3}{*}{ 外向 } & 感覚 & $0(0.0)$ & $18(18.0)$ & 18 \\
\hline & 直観 & $0(0.0)$ & $9(9.0)$ & 9 \\
\hline & 計 & $0(0.0)$ & $27(27.0)$ & 27 \\
\hline \multirow{3}{*}{ 内向 } & 感覚 & $27(24.9)$ & $12(14.1)$ & 39 \\
\hline & 直観 & $3(5.1)$ & $5(2.9)$ & 8 \\
\hline & 計 & $30(30.0)$ & $17(17.0)$ & 47 \\
\hline \multicolumn{2}{|c|}{ 計 } & 30 & 44 & 74 \\
\hline
\end{tabular}

Note. カッコ内は期待度数.

のタイプとミステイクにおける原因とのクロス表であ る. 判断機能のタイプを構えのタイプ (外向, 内向) で 層別化したマンテル・ヘンツェル検定を行った結果, 漸 近有意確率 (両側) $: p=0.994>.05$, 推定值0.950. 95 \% CI $[0.498,1.810]$ となり，統計的に有意な連関は認 められなかった。

\section{4 認知不良の起因 (分析項目 2)}

ミステイクの原因が，認知不良になった者（74名）を 分析対象として, 知覚機能におけるタイプ (感覚, 直観) の違いが, 起因（外因, 内因）の違いに連関しているか を検証した. 表 6 は, 個人が推定した知覚機能のタイプ と, 個人が自覚した認知不良の起因のクロス表である. 構え (外向, 内向) で層別化したマンテル・ヘンツェル 検定を行った結果, 漸近有意確率 (両側) : $p=0.199>$ .05，95\% CI [0.769，18.291] となり，統計的に有意な 連関は認められなかった。この結果は，95\%信頼区間に オッズ比 1 を含むため, 帰無仮説（どの層でも関連がな い=各層のオッズ比が共通でその值が 1 になる）が棄却 されず, 対立仮説（各層が 1 でないある共通の傾向の才 ッズ比をもつ）が重却されたわけであるが, その理由を 考えてみると, 構えの夕イプが外向か内向かで, 感覚と 直観のオッズ比が逆方向になったと考えられた. そこで, 構え (外向, 内向) の夕イプと知覚機能（感覚, 直観) のタイプを組み合わせた 4 種類の組み合わせ（外向・感 覚, 外向・直観, 内向・感覚, 内向・直観）をつくり, 起因（外因, 内因）と連関するかを検証した。表 7 は, 4 種類の組み合わせと, 認知不良の起因のクロス表であ る. 表 7 には, 期待度数で 5 未満のセルがあったため, フィッシャーの正確確率検定を行った。 その結果, 正確
表 74 種類のタイプ組み合わせと起因のクロス表

\begin{tabular}{|c|r|r|r|}
\hline \multirow{2}{*}{} & \multicolumn{2}{|c|}{ 認知不良の原因 } & \multirow{2}{*}{ 計 } \\
\cline { 1 - 3 } & 外因 & 内因 & \\
\hline 外向・感覚 & $0(7.3)$ & $18(10.7)$ & 18 \\
\hline 外向・直観 & $0(3.6)$ & $9(5.4)$ & 9 \\
\hline 内向・感覚 & $27(15.8)$ & $12(23.2)$ & 39 \\
\hline 内向・直観 & $3(3.2)$ & $5(4.8)$ & 8 \\
\hline 計 & 30 & 44 & 74 \\
\hline
\end{tabular}

Note. カッコ内は期待度数.

表 84 種類のタイプ組み合わせと起因の残差分析

\begin{tabular}{|c|c|c|}
\hline \multirow{2}{*}{} & \multicolumn{2}{|c|}{ 認知不良の原因 } \\
\cline { 1 - 3 } & 外因 & 内因 \\
\hline 外向・感覚 & $-4.027^{* *}$ & $4.027^{* *}$ \\
\hline 外向・直観 & $-2.643^{* *}$ & $2.643^{* *}$ \\
\hline 内向・感覚 & $5.306^{* *}$ & $-5.306^{* *}$ \\
\hline 内向・直観 & -0.185 n.s. & 0.185 n.s. \\
\hline
\end{tabular}

Note. $^{*}: p<.05,{ }^{* *}: p<.01$. n.s. : not significant.

な有意確率 (両側) $: p=0.000000013<.01$ となり, 統 計的に有意な連関が危険率 $1 \%$ で認められた。

残差分析を行ったところ，表 8 の結果になった.

まず，認知不良の起因を外因とした者については，内 向・感覚の者だけが, 有意に多かった $(p<.01)$. 外向・ 感覚, 外向·直観の者は, 有意に少なかった $(p<.01)$.

次に，認知不良の起因を内因とした者については，内 向·感覚の者だけ, 有意に少なかった $(p<.01)$. 外向. 感覚, 外向・直観の者は, 有意に多かった $(p<.01)$.

内向・直観の者は, 外因, 内因とも有意にはならなか った $(\mid$ 残差 $\mid<1.96=$ n.s. $)$.

\section{5 考察}

ミステイクの原因を思い込みとした者に押いて, 直観 が有意に多かったのは, 感覚が細かな事実を求めようと するのに対して, 直観は全体のイメージで捉えようとす るため, とくに課題に似た先行体験のイメージが残って いると，それに引きずられて思い込みを起こしやすくな ったと思われる（例：新入生合宿でパス夕を使い高さを 競ったことが先入観になったという記述があった)。他 方, ミステイクの原因を認知不良とした者においては, 同じ感覚でも構えの違いによって逆の結果になった。す なわち, 外因では, 内向・感覚の組合せだけが有意にな ったが，内因では，知覚の違いに関係なく外向であれば 有意になった，感覚が内向と組み合わさると，具体的な 周囲の情報をじっくり正確に取り入れようとする性向に なるため, チーム内の状況が自分のペースを乱したとき は，しっかり読めなかったという外因を感じたと思われ る. 逆に, 外向は活動的な性向になるため, 行き過ぎる とあわてた動きになり，しっかり読まなかったという内 因を感じたと思われる。とくに感覚が外向と組み合わさ ると周囲の情報を具体的活動的に取り入れようとする。 一方, ミステイクの原因と判断機能のタイプに連関が認 められなかったのは, 思い込みや認知不良が, 知覚段階 
で失敗したことによるものであったためと考える.

本研究の結果は, 夕イプが自分らしさの源泉になると ともに無自覚にふるまうと自他に悪影響を及ぼすことが あること，また，特定の条件（例：似た先行体験. 慌て させられる状況. ) があるとタイプによってはミステイク が誘発されやすくなることを示唆したと考える.

\section{6 実践的示唆}

期末レポートに,「自分のどちらに指向があるのか仮説 を立てることができた。 その仮説を意識して周囲の環境 に適応していくのと，その仮説なしに適応していくので は意味が違ってくる．自分の指向を意識して周囲に関わ っていきたい.」という記述があった. 学生に対しては, 自分の起こしやすい起因に気づかせること，意識して行 動するための知識を与えることが有用と考える.

\section{5. 結論}

本研究の目的は，チーム演習で個人が自覚したミステ イクの起こし方と心理学的タイプとの間に，連関がある かを検証することであった，全調査対象者 (250名) のう ち、ミステイクを自覚した（自分に関する問題意識を持 つた）者が160名（64\%）おり, 分析対象者とした。検証 では，用語の操作的定義をしたうえで，期末レポートの 記述回答を分類して，一人ひとりのタイプとミステイク の起こし方を同定し，クロス表を作成した。 クロス表の 統計的検定では, 独立性の検定（マンテル・ヘンツェル 検定やフィッシャーの正確確率検定）を行った。その結

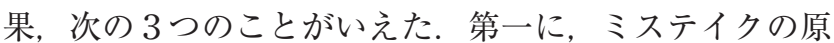
因を思い込みとした者は, 直観が有意に多く $(p<.01)$, 感覚が有意に少なかった $(p<.01)$ ，逆に，ミステイク の原因を認知不良とした者は，感覚が有意に多く（ $p<$ $.01)$ ，直観が有意に少なかった $(p<.01)$. 第二に, ミ ステイクの原因については, 判断機能との連関は統計的 に認められなかった。第三に，認知不良の起因について は, 外因とした者は, 内向・感覚の者のみ有意に多かっ た $(p<.01)$. 逆に, 内因とした者は, 外向との組み合 わせで有意に多かった（ $p<.01 ）$ が, とくに感覚との組 み合わせで強い連関があった。本研究は，今後，多様な 調査対象者を取り込む必要があるため, 検証結果は暫定 的に扱うことが妥当と考えるが，チームワーク教育を考 えていくうえで, ミステイクの発生を予防・低減するた めの手掛かりになり得ると考える.

\section{参 考 文 献}

1) 文部科学省：学士課程教育の構築に向けて(答申). 中央教育審議会, Webページ, http://www.mext. go.jp/b_menu/shingi/chukyo/chukyo0/toushin/ 12170 67.htm, 2008, 参照日：2020-2-9

2 ）有信睦弘：社会と連携したイノベーション教育の必 要性と重要性, 工学教育, 63-1, pp.13-17, 2015

3) J.リーズン, 林 喜男 (監訳) : ヒューマンエラーー認 知科学的アプローチー, 海文堂, p.15, 1994

4 ) 抄録の検索結果は, CiNii Articles：0件(チーム, ヒュ ーマンエラー, ユング, タイプ), Scopus：0 件(team, “human error”, Jung, type)であった。（検索日： 2019-9-16)

5 ）福島哲夫：ユング・タイプ論から考える自己理解・他 者理解, 成城カウンセリングオフィス出版部, 2018

6 ）河合隼雄：ユング心理学入門, 培風館, pp. $37-57$, 1967

7 ）杉本洋一, 荒川雅生, 石丸昌彦 : チーム内の相補的協 働を促進するためのチームワーク教育の試みと検 証, 工学教育, $67-4$, pp.38-43, 2019

8 ）福田収一：デザイン工学, 放送大学教育振興会, pp. $43-47,2008$

9 ) D. J.ワイルド : Teamology : the construction and organization of effective teams, Springer Science \& Business Media, 2008

10）飯野謙次：ユングの性格論を利用したチーム形成, 機械の研究, $59-1$, pp.155-162, 2007

11) I. B.マイヤーズ, P. B.マイヤーズ : Gifts differing : Understanding personality type, Nicholas Brealey, 2010

12) R. R.ピアマン, C. A.サラ : I'm not crazy, I'm just not you: The real meaning of the 16 personality types. Nicholas Brealey, pp.32-36, 2010

\section{著者紹介}

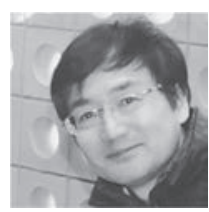
杉本 洋一

学 歴 放送大学大学院文化科学研究科修士課程修了 現 職 香川大学創造工学部創造工学科准教授 学 位 修士 (学術) 所属学会 日本機械学会 他 